\title{
Tenzin Chodron: a scholar nun of post-Soviet Buryatia
}

Zhargal Aiakova

\author{
Correspondence: azhargal@yandex.ru \\ Department of Public Relations, \\ Sociology and Political Sciences, \\ Buryat State Academy of \\ Agriculture, Pushkina st., Ulan-Ude \\ 670024, Russia
}

\begin{abstract}
Tenzin Chodron (b. 1951) is a scholar nun who has opened up new pathways for Buddhist women in the Republic of Buryatia. The paper describes how, at a critical juncture in the political and religious transition from Soviet rule to greater openness as a member state of the Russian Federation, she has endeavored to bring together scholarship, social activism, and religious life. An introduction to the Buddhist history of Buryatia serves as the backdrop for Tenzin Chodron's autobiographical materials, which discuss her early life, education, professional work, and social engagement, with the aim of bringing to light the ways that women can realize their potential and play important roles in post-Soviet Buryat society. The example of Tenzin Chodron illustrates that, like men, women have the right to be ordained, at least as novices, and to be educated in the rigorous Buddhist philosophical tradition that has been carefully preserved through the cold winter of religious persecutions in this region of Siberia. Like many other nuns in the contemporary world, her active engagement in society is helping to shape a new international Buddhist conversation that gives women a greater voice and signals to Buddhist institutional authorities that women can indeed become Buddhist masters.
\end{abstract}

Keywords: Buryat women, Buddhist nuns, Tenzin Chodron, Tibetan Buddhism, Buddhist philosophy

\section{Review}

\section{Buddhism in Buryatia}

The key elements of Buddhist doctrine - the Four Noble Truths, the Eightfold Path, the Twelve Links of Dependent Arising (pratityasamutpada) - are the essence of the Buddhist tradition adopted by the Tibetans, Buryats, and Mongols. During its more than 2,500 years of existence, Buddhism has undergone profound changes, yet the essence of the Buddha's Dharma (the path to awakening) has been preserved through the ages unchanged. In the canonical literature of the Tibetan Buddhist tradition, we find all the main teachings attributed to Shakyamuni Buddha, including the transitory nature of all compounded phenomena, the pervasiveness of suffering, the connection between human suffering and actions created in previous rebirths, as well as the way to overcome suffering and become free from the craving for existence. In Buryatia, the Four Noble Truths became the guiding principles for Buddhist followers, impelling them to meditate on the nature of existence and the meaning of life. As elucidated in the Buddha's teachings and practiced on the Eightfold Path, all happiness and misfortune, in this and future lives, depends on understanding the immutable law of karma.

(c) 2016 Aiakova. Open Access This article is distributed under the terms of the Creative Commons Attribution 4.0 International License (http://creativecommons.org/licenses/by/4.0/), which permits unrestricted use, distribution, and reproduction in any medium, provided you give appropriate credit to the original author(s) and the source, provide a link to the Creative Commons license, and indicate if changes were made. 
The impersonal law of cause and effect places the responsibility for all actions on the individuals concerned and evolution on the path means abstaining from the ten nonvirtuous actions: three of body, four of speech, and three of mind. The Twelve Links of Dependent Arising explains the process of causation that traps sentient being in the wheel of cyclic existence (samsara) and also the process of achieving liberation.

In the seventeenth century, Tibetan Buddhism came to Buryatia from Mongolia and Tibet, and spread among the Buryats inhabiting the region of Transbaikalia. The Gelug tradition predominated and Guru Tsongkhapa, the founder of the Gelug tradition, was revered by the Buryat people on a par with Sakyamuni Buddha. By the end of the nineteenth century, Buddhism in Buryatia had become a sophisticated religious system. As a result, there was intensive construction of monasteries, shrines, and several stupas. Schools of theology, philosophy, medicine, and astrology were established, as were foundries producing Buddhist religious art and ornamentation. Buddhism became an inseparable part of Buryat life and contributed greatly to the people's social development (Lepekhov 2002, 25).

Some transformations and modifications took place due to the influences of local religious and cultural traditions. As Buddhism became widespread throughout Buryat territory, it interacted with important shamanic deities and rituals, which became incorporated into Buddhist practice. Buryat and Tibetan Buddhists demonstrate their unique refraction of the Mahayana tradition in their rituals and magical practices. These modifications are due to the influence of traditional, more ancient and archaic beliefs, practices, and rituals of the Tibetans and Buryat Mongols that predate the introduction of Buddhism. In its philosophical, psychological and ethical teachings, Buryat Buddhism does not differ significantly from the fundamental provisions of Mahayana Buddhism as presented in the Tibetan version of the Buddhist canon.

Buryatia women's attitudes are strongly influenced by the all-male Buddhist clergy's belief in women's inferior status. For most Buryat Buddhist women, only a man can be a genuine lama and teacher. Hence, it is widely believed that only males are genuine Buddhist practitioners and teachers. A woman's gender is conditioned by her karma and to be a woman is considered an unfortunate consequence of her actions in a previous life. In modern Buryat families, men and women are recognized as equal, with husbands and wives equally responsibility for the welfare of the family. The worldviews of Buryat women are becoming transformed (Tsomo 2015). Their knowledge about the roots of Buddhism and about the equality of women and men in all spheres of social and spiritual life is growing. But as a patriarchal society, it is impossible to maintain egalitarian principles of human coexistence. The patriarchal mentality is evident in all areas of life, in traditions and customs, and in the lifestyle of Buryat women. The men in the family - husbands, brothers, and sons - are respected as superior creatures to women. Violation of these norms by a woman is considered to be the result of a lack of appropriate education in her family and disrespectful to Buryat traditions and culture. A Buryat woman considers her karma in terms of how to earn merit in this life in order to be born as a man in future lives, and thereby have the good fortune to travel along the path to enlightenment. This point of view is pervasive in Buryatia even today, even though His Holiness the $14^{\text {th }}$ Dalai Lama says that men and women have equal potential to attain enlightenment and liberation.

During Soviet period Buryat Buddhist women had to be very careful about receiving religious instruction and empowerments. Due to unfavorable state policies, most 
women conscientiously hid their Buddhist identity and avoided overt demonstrations of religious behavior. Some women shaved their heads, however, and some wore an orhimzho, a kind of a long scarf of red or maroon color draped over the left shoulder. The Buryat word orhimzho means to leave or escape, implying to leave mundane life (Budozhapova 2012, 66). For that reason, they were disparagingly called shabgantsa and subjected to sarcasm (Budozhapova 2012, 16).

\section{The life of Tenzin Chodron}

Today the situation of Buddhist women in Buryatia is improving. Contemporary Buryat women are educated and have different opportunities to realize themselves in many areas of social life including religion. Buryat women openly practice Buddhist religion and, more importantly, they study Buddhist philosophy and are engaged in social activities to revive and spread Buddhist values among the population. Among these dynamic women is the Buryat nun Tenzin Chodron (Irina Urbanayeva), who has taken the precepts of a novice nun (getsulma). She holds a doctoral degree in Philosophy and currently works as a researcher at the Institute of Mongolian, Buddhist, and Tibetan Studies in Ulan-Ude, Republic of Buryatia.

Tenzin Chodron was born in Olkhon, a place near Lake Baikal that is considered sacred by the Buryat people. Olkhon is also famous as the native place of a Buryat man named Barnashka. This man was very well-known among the Buryats in the twentieth century due to his extraordinary ability to foretell future events, predictions that usually came true. Tenzin Chodron related:

My mother mentioned Barnaskha every time an event transpired just as Barnashka had predicted it would. People regarded him as a shaman, but I later learned that he was a Buddhist. For some time, he practiced at a monastery known as Datsan Tunkinskiy. During prayers, he sat at the right hand of Lama Shiretuy, who was the abbot of the monastery (Chodron 2016).

Tenzin Chodron kept in mind these memories of the place where she was born. As a young adult, these recollections helped her recall her physical and spiritual roots. This was during the Soviet era, a time when all evidence of Buddhism in Buryatia had been erased, due to the anti-religious state ideology. Tenzin Chodron's parents were formally atheists, as was required at the time. By origin, she belonged to an ethnic group known as the Irkutsk Buryats or Western Buryats. Traditionally, the Irkutsk Buryats are said to be shamanistic by faith, but she rejects that claim. Her research led her to the conclusion that not all Irkutsk Buryats were shamanists; some were also Buddhists. In her analysis, the presence of two Buddhist monasteries (datsan) in the Irkutsk region Selo Sarantsy and Skala Shamanka - proves that there were Buddhists among the Irkutsk Buryats. It is an historical fact that some Tibetan monks meditated at Olkhon. Moreover, Olkhon is considered to be a residence of the Buddhist deity Paldan Lhamo.

Reflecting on her own family's connections with Buddhism, Tenzin Chodron recalls:

My grandfather on my father's side had no children for a long time. After some time, my grandfather took refuge at Tamchinsky Datsan, where he was given some Buddhist relics. These relics were kept for a long time by his family. After he had 
children, they were entrusted with keeping the relics and with preserving the story of the relics as a family treasure. Later, during Stalin's political repressions, my grandfather was arrested and, as was common at that time, his fate is unknown.

My mother's father was a communist and Buryat nationalist patriot. He was very worried about his family and decided to move them to Selo Egita, where today there is a famous sandlewood Buddha enshrined at Egituyskiy Datsan. Later, he was also arrested and nobody has any information about his fate.

My father worked as the director of a school. Any evidence of Buddhism was strongly prohibited in my family - no Buddhist relics, books, even conversations on Buddhism were allowed. Because Buddhism has been maintained as a folk tradition, my mother secretly visited the datsan and lamas, because she always felt a need for spiritual and moral support. My father usually drove her on these visits to the datsan and waited for her outside, sitting in the car somewhere, so nobody could see him (Chodron 2016).

One incident left a deep impression on Tenzin Chodron's consciousness, because if ran counter to the regime's anti-religious ideology and contravened the rules and norms of Soviet society:

When I was in school, I had a classmate who invited me to her home. Nearby, there was a little house where (I later learned) her grandfather stayed and practiced meditation. I never saw him, but my classmate told that he meditated and recited mantras all the time, with only short pauses for taking food and drink. Now I realize that he was in an intensive retreat and was a dedicated Buddhist practitioner. At the time, I was very impressed by the thought of this old man sitting in meditation posture and continuously reciting mantras. It caused me to reflect, because, at the time, this was something extraordinary (Chodron 2016).

Another event that had major impact on Tenzin Chodron and encouraged her on the Buddhist path occurred when she was a student of the Department of Philosophy at Moscow State University. Her family moved to the village of Baryun Hasurta and there her mother became acquainted with two shabgantsa, older women with shaved heads who observed five Buddhist precepts (Syrtypova 1998, 17). These women lived together and prayed all the time in front of the Buddhist altar in their home. Her mother and father became their caretakers, treating them as if they were their own mothers. Since they had no parents of their own, they wanted the women to feel like their closest relatives. The shabgantsas had taken Mahāyāna vows and were genuine Buddhist practitioners, even yoginis. When Tenzin Chodron visited her parents during her vacations, she observed the women, trying to understand their practice and hoping to get some idea about Buddhism in general. When the two women went away, they left their altar with a statue of Avalokiteśvara, a very beautiful prayer wheel apparently made in China, and a copy of the Sutra of Golden Radiance (Buryat: Altan Gerel) for her mother. Tenzin Chodron keeps the statue of Avalokiteśvara on her altar today to this day. At this stage, Buddhism became associated with mystery and wonder in her mind: 
One day, my mother met a pilgrim who was a tantric practitioner of chod (Buryat: zhodchin) and invited him to our place, where he performed tsog. In tantric Buddhism, tsog is an offering ceremony performed to purify the mind, eliminate all obstacles, and accumulate merit and wisdom toward the goal of perfect awakening. That time we were not allowed to observe this ceremony, but my younger sister managed to take a peak while hiding behind the fence. She told us that, at the end of this practice, a big plate of food was brought out the house and scattered about. Suddenly, she heard loud sounds like dogs barking and eating the food, but there were no dogs to be seen! We decided that hungry ghosts had visited our house (Chodron 2016).

As a student, Tenzin Chodron was interested in philosophy in general. At that time, students at the universities studied Russian and Western philosophy, and the courses included no information about Buddhist philosophy or Buddhist teachings. The meaning of life and the problem of death were questions of central importance for her, but at the university she was not able to find satisfactory explanations or answers to her many questions.

At this point, Tenzin Chodron began to feel a strong need for guidance and teachings. In the end, her spiritual quest led her to the Buddhist philosopher and yogin Geshe Jampa Thinley. When this Tibetan lama came to Buryatia in 1993 as the Spiritual Representative of His Holiness the $14^{\text {th }}$ Dalai Lama to Russia, news of his visit was not widely disseminated. There was no publicity and no mass media announcing the event. Tenzin Chodron received information about the event accidentally, but it went straight to her heart. She had a feeling that Geshe Thinley was the right person to teach her and lead her along the Buddhist path. Since the time of their first meeting, she has followed Geshe Thinley, who has worked tirelessly to help restore Buddhist traditions and has given teachings all over Russia, especially in the three Buddhist regions of Buryatia, Kalmykia, and Tuva.

Tenzin Chodron's next challenge was to make an effort to reconcile her newfound interest in traditional Buddhist teachings with her personal and professional life:

As I now understand, I had a long way to go to develop a deep understanding the Buddhist teachings. But at the time, after that first meeting, I still had to continue with my everyday work in the Buryat Scientific Center and my public activities as a leader of the Union of Buryat Intelligentsia. This organization aimed to support Buryat intellectuals in their efforts to restore Buryat traditions and Buddhist culture. I was very active in the social and political life of Buryatia. At that time, during the $1980 \mathrm{~s}$ and 1990s, I was known to be a Buryat extremist and nationalist, speaking out against the Communist Party. It is difficult to assess which direction was right or wrong, but gradually I realized that I needed to transform myself and found it very important to try to understand more about my inner world (Chodron 2016).

As she began to devote more time to her spiritual development, her social activities became more closely entwined with Buddhism and she made Buddhist friends.

As Tenzin Chodron learned more about Buddhism and reflected on her personal development on the Buddhist path, she became more devoted and eventually came to 
the decision to become ordained as a nun. Geshe Thinley approved her decision and advised her to go to India where he and some of his teachers, including Geshe Namgyal Wangchen and Geshe Sopa Rinpoche, could ordain her. In 2002, she went to India with a group of Buryat pilgrims to attend the Kalachakra empowerment ceremony, which unfortunately was canceled due to the illness of H. H. Dalai Lama. In Bodhgaya, Geshe Namgyal Wangchen and Geshe Thinley ordained her with the vows of renunciation (rabchung). In 2003, she was ordained as a novice nun (getsulma) by H. H. Dalai Lama in Dharamsala. Three women were ordained as nuns at that ordination ceremony: two from Buryatya and one from Moscow. However, nuns are not regarded as equal to monks in Buryat society and, generally speaking, are not taken seriously. They are considered unusual and outside the mainstream in Buryat society. For these reasons, two of the nuns ordained at that time later disrobed.

Only a few lay people in Buryatia know about the existence of Buddhist nuns and their activities. The example of Tenzin Chodron illustrates that, like men, women have the right to be ordained, at least as a novice, and to be educated in a rigorous Buddhist philosophical way. Like many other nuns in the contemporary world, she is actively engaged in society. For example, in 2005, in the center of Ulan Ude, she organized a large-scale meeting and collected the signatures of Buddhist followers and lay people to invite His Holiness the $14^{\text {th }}$ Dalai Lama to visit Buryatia. Despite her best efforts, the Russian government did not grant a visa for His Holiness to visit Buryatia. Tenzin Chodron was able to attract the attention of all the local mass-media resources, but all their efforts were unsuccessful. Russia and China have been building what they call a "strategic partnership," so in recent years, Moscow has wished to maintain good relations with China.

Buryat Buddhists aspire to see His Holiness on Buryat land once again and keep the hope that one day their dream will come true. Tenzin Chodron asks, "What kind of freedom of conscience can we claim if we have no chance to see our Buddhist leader the $14^{\text {th }}$ Dalai Lama in Buryatia and other Buddhist regions in Russia - Kalmykia and Tuva?" (Bochanova 2008). She initiated a letter to Putin, the President of the Russian Federation, in which Buryat Buddhists expressed their resentment toward the position of silence that Russia has maintained regarding the violent crackdown on peaceful protests in Tibet since March 10, 2008. The signers requested the Russian government not to close its eyes to the Tibet issue, but instead to act as a mediator in negotiations between the Chinese government and the $14^{\text {th }}$ Dalai Lama as a positive contribution to resolving the conflict. Buryat Buddhists are deeply concerned about the situation in Tibet and pray for the Dalai Lama and all the Tibetan people. Tenzin Chodron believes that for Buddhists in Butyatia, Kalmykia, and Tuva, the Tibetans are brothers and sisters, and the Buryats cannot remain indifferent to their hardships. So far there has been no answer from the President, but the Ministry of Foreign Affairs has stated that resolving the conflict was an internal affair. Tenzin Chodron replied, "For all the world community the $14^{\text {th }}$ Dalai Lama is a great personality, Nobel Peace Prize laureate, philosopher, political and religious leader, and preacher of peace throughout the world. The most precious figure that the Tibetan people have is the Dalai Lam. It is difficult to describe how they treat and love His Holiness. In himself, he represents all that is sacred and precious to the Tibetans in their history, which is all connected with their culture, faith, and hope" (Bochanova 2008). 
As the leader of the Green Tara (Nogor Dara Ekhe) Buddhist community, Tenzin Chodron has been active in society for many years. Green Tara has used a holistic approach to community development, working in research, publications, training, and social mobilization. Members aim to bridge the gap between rural and urban, rich and poor, and men and women in accessing services and improving their health and well-being through community development, philosophy, principles, and ethics.

\section{Buryat Buddhism in an International Context}

Tenzin Chodron has been exploring Tibetan Buddhism, history, and culture, as well as the so-called Tibet issue. Having traveled to the countries where Tibetan refugees live, such as India, Nepal, China, and Mongolia, she has explored the life of the Tibetans and Tibetan Buddhist monasteries, which has allowed her to gather extensive research materials for many publications and monographs. When speaking about Tibet's unique culture and how the Tibetans have managed to maintain their Buddhist teachings and traditions, Tenzin Chodron repeatedly emphasizes that the preservation of Tibetan language and culture means the preservation of Buddhism in general. Her research interests include Tibetan Buddhism, logic, meditation, Tibetan written and oral sources, and the relationships between Buddhism and science. One way she pursues these interests is through her position as the leading editor of Je Tsongkhapa Publishing House, which is dedicated to spreading the teachings of the Buddha in Russia and to publishing the texts of great Buddhist masters in Russian and Buryat languages (Ayusheeva and Yangutov 2011, 246).

Tenzin Chodron is the author of more than one hundred publications. Her knowledge of Tibetan language allows her to translate many philosophical texts and to adapt them for Russian readers in a way that expresses deep wisdom and insight. Today, due to her diligent efforts, Russian and Buryat people are discovering the principals of Buddhism as philosophy and science. Among her recent books that have been published in Buryatia are Buddhist Philosophy and Meditation in Comparative Context, Based on the Indo-Tibetan Texts and Oral Traditions of Tibetan Buddhism and The Formation of Tibetan and Chinese Mahayana in the Context of Authentic Buddhism Problems. In the first book, she studies the rationalist approach of Buddhism in comparison with the cognitive approach of modern science and Western philosophy. She explains the relationship between Buddhist philosophy and meditation as presented in the Indo-Tibetan tradition and explores the meaning of the Nalanda scholarly heritage as preserved in the Tibetan Buddhist tradition. In the second book, she examines the most important aspects of Tibetan and Chinese Buddhism in a comparative format to better understand their objectives and the cultural and psychological factors and strategies that influenced the development of Buddhism in Tibet and China.

Tenzin Chodron's vast scholarship can be summarized in what is explained as the union of wisdom and method: "The doctrine of śünyatā (emptiness) is related to what is called the ultimate bodhichitta. The highest bodhicitta is the mind that comprehends śünyatā in conjunction with conventional bodhicitta. The conventional bodhicitta is love and compassion toward all sentient beings. One of the central Buddhist prayers is, 'May I become a Buddha for the sake of the happiness of all sentient beings.' In my opinion, we must pay attention to this altruistic message if we want to liberate 
ourselves and achieve awakening" (Bochanova 2008). This message represents the core of the Buddhist teachings that Tenzin Chodron shares with the Buryat people.

\section{Conclusion}

Buddhism has spread all over the world as a religion and philosophy. For Buryat people it remains to be seen as a religion rather than a philosophy. But it doesn't say the Buryats believe blindly in the supernatural or superpower beings capable to satisfy their wishes and dreams. But they believe consciously in Buddha, Dharma and Sangha seeking for the very natural truth of the existance. The spiritual or moral values such as patience or loving kindness are natural phenomenas but they are superpowerful indeed. This is the core of the Buddhist religion and philosophy. As a Buddhist practicioner and a Doctor of Buddhist philosophy Ven. Tenzin Chodron trasmits the Teaching to the Buryat belivers in both ways: religious and philosophical. The way of life of Ven.Tenzin Chodron maybe was not so heroic, full of dramatic or extraordinary events but she is very unique phenomena in Buryatia. Her way was ordinary in a sense that the most of Buryat women of the time grew up in the atheistic atmosphere and got a higher education in the institutions and universities. Ven. Tenzin Chodron had managed to overcome that standard of life and had a great courage and inner freedom to change her life to serve the people. It is not that has she changed the society or not or going to do this, but the fact of her presence is a hopeful beginning for the awakening of Buryat women.

Competing of interests

The authors declare that they have no competing interests.

Received: 28 February 2015 Accepted: 30 June 2016

Published online: 28 September 2016

\section{References}

Lepekhov, Sergey. 2002. "Monasteries and philosophical schools as the key elements in Buddhist civilization", in Buddhism in Buryatia: history and modernity [in Russian]. Ulan-Ude: Buryat State University.

Tsomo, Karma Lekshe. 2015. In "Transition and Transformation: Buddhist Women of Buryatia." Buddhism in Mongolian History, Society, and Culture, ed. Wallace Vesna, 261-279. New York: Oxford University Press.

Budozhapova, Larisa. 2012. Buddhist Terminology in Buryat language [in Russian]. Ulan Ude: Buryat State University.

Chodron, Tenzin. Interview by author. Tape recording. Ulan-Ude, February 26, 2016.

Syrtypova, Surun-Handa. 1998. Female deities in Buddhist confession in Buryatia (PhD.diss.). Ulan-Ude: The Institute for Mongolian, Buddhist and Tibetan Studies.

Bochanova, Larisa. 2008. An interview with Ven. Tenzin Chodron (Irina Urbanayeva) [in Russian]. http://savetibet.ru/ 2008/07/21/irina_urbanaeva.html. Accessed 21 July 2008.

Ayusheeva, Dulma, and Leonid Yangutov. 2011. "Irina Urbanayeva: a prominent scholar in the field of Buddhist philosophy" [in Russian]. Ulan-Ude: Vestnik Buryatskogo Nauchnogo Tsentra.

\section{Submit your manuscript to a SpringerOpen ${ }^{\circ}$ journal and benefit from:}

- Convenient online submission

- Rigorous peer review

- Immediate publication on acceptance

- Open access: articles freely available online

- High visibility within the field

- Retaining the copyright to your article

Submit your next manuscript at $\downarrow$ springeropen.com 